\title{
Upaya Peningkatan Ketrampilan Berpikir Kritis dan Hasil Belajar Mata Pelajaran PKn melalui Metode Bermain Peran
}

\author{
Rizkika Amatullah Zahra ${ }^{1 *}$, Stefanus C Relmasira², Janelle Lee Juneau ${ }^{3}$
}

1,2,3 SD Negeri Bringin 3 Kabupaten Semarang.

\author{
A R T I C L E I N F O \\ Article history: \\ Received 22 February 2018 \\ Received in revised form \\ 7 March 2018 \\ Accepted 20 April 2018 \\ Available online 26 May \\ 2018 \\ Kata Kunci: \\ ketrampilan berpikir kritis, \\ hasil belajar, bermain \\ peran, $P K n$. \\ Keywords: \\ critical thinking skills, \\ learning outcomes, role \\ playing, Civic Education
}

\begin{abstract}
A B S T R A K
Penelitian ini merupakan penelitian tindakan kelas yang bertujuan untuk meningkatkan ketrampilan berpikir kritis dan hasil belajar siswa dengan menggunakan metode bermain peran pada mata pelajaran PKn. Data dikumpulkan dengan menggunakan lembar observasi dan soal evaluasi pada setiap akhir siklus. Data ketrampilan berpikir kritis didapat dengan menjumlah semua skor dalam 5 indikator dan membaginya dengan jumlah skor maksimal kemudian dikalikan 100 dengan perolehan skor 49 dengan kriteria cukup kritis pada siklus I dan mengalami peningkatan perolehan skor menjadi 63 dengan kriteria kritis pada siklus II. Dari presentase ketuntasan hasil belajar $11 \%$ pada pra siklus meningkat menjadi $66,7 \%$ pada siklus I dan kembali meningkat menjadi $83 \%$ pada siklus II. Hal ini membuktikan bahwa penggunaan metode bermain peran dapat meningkatkan ketrampilan berpikir kritis dan hasil belajar siswa.
\end{abstract}

\section{A B S T R A C T}

This is a classroom action research oriented to improve students' critical thinking skills and learning outcomes that use role playing method in Civics Education. The data will be collected using observation and evaluation sheets at the end of each cycle. Data for critical thinking skill are obtained by summing all scores of 5 indicators and divide them by the maximum scores then multiplied by 100 . The result in the first cycle is 49 with category critical and there is improvement in the second cycle which score 63 with category slightly critical. Students' learning outcome also improved from $11 \%$ before the classroom action to become $66,7 \%$ in the first cycle and become $83 \%$ in the second cycle. It proves that the use of role playing method in Civic Education can improve students' critical thinking skills and students' learning outcomes. 


\section{Pendahuluan}

Menurut Slameto (2010) belajar adalah suatu proses usaha yang dilakukan seseorang untuk memperoleh suatu perubahan tingkah laku yang baru secara keseluruhan, sebagai pengalamannya sendiri dalam interaksi dalam lingkungannya. Hasil belajar diperoleh jika terjadi perubahan tingkah laku dari tidak tahu menajdi tahu dan dari tidak mengerti menjadi mengerti. Perubahan tersebut dapat diartikan terjadinya peningkatan dan perkembangan yang lebih baik dari sebelumnya (Marsiyanti,2015).

Pendidikan Kewarganegaraan adalah pendidikan yang mengkaji dan membahas tentang pemerintah, konstitusi, lembaga-lembaga, demokrasi, rule of law, HAM (Hak Asasi Manusia), hak dan kewajiban warga negara, serta proses demokrasi (Sulasmono, 2010). Menurut Bakry (2011) pendidikan kewarganegaraan (PKn) bertujuan untuk menumbuhkan kesadaran berbangsa dan bernegara serta berjiwa demokratis yang berkeadaban.

Pendidikan Kewarganegaraan (PKn) merupakan salah satu pendidikan yang penting dan dibutuhkan siswa untuk membentuk watak dan tingkah laku manusia sebagai warga negara Indonesia. Tujuan PKn pada dasarnya adalah menjadikan warga negara yang cerdas dan baik serta mampu mendukung keberlangsungan bangsa dan negara (Ubaidillah, 2008).Dalam Standar Isi untuk Satuan Pendidikan Dasar dan Menengah yang diterbitkan Dediknas tahun 2006 dijelaskan bahwa Mata Pelajaran Pendidikan Kewarganegaraan merupakan mata pelajaran yang memfokuskan pada pembentukan warga negara yang memahami dan mampu melaksanakan hakhak dan kewajibannya untuk menjadi warga negara Indonesia yang cerdas, terampil,dan berkarakter yang diamanatkan oleh Pancasila dan UUD 1945 (Dediknas,2006). Salah satu tujuan mata pelajaran PKn adalah membuat peserta didik memiliki kemampuan berpikir secara kritis,rasional, dan kreatif dalam menanggapi isu kewarganegaraan.Menurut Fisher (2007) berpikir ktitis adalah interpretasi dan evaluasi yang terampil dan aktif terhadap observasi dan komunikasi, informasi dan argumentasi. Dalam berpikir kritis siswa dapat meningkatkan kemampuannya dalam memahami materi yang disampaikan dan siswa juga dapat memecahkan permasalahan serta mendapatkan solusi dari permasalahan yang ada.

Berdasarkan observasi dan wawancara dengan guru kelas SDN Bringin 3 yang dilakukan peniliti, ditemukan beberapa hal diantaranya: 1). Kegiatan pembelajaran yang terlihat satu arah dan berpusat pada guru, 2). Dalam melaksanakan kegiatan pembelajaran, guru menggunakan satu metode yaitu metode ceramah dan belum mengembangkan metode lain yang lebih mengajak siswa untuk aktif berpartisipasi dalam pembelajaran, 3). Dilihat dari cara siswa mengerjakan soal, siswa masih kesulitan dalam menganalisis dan memecahkan masalah yang ada dalam soal yang menjadikan ketrampilan berpikir kritis siswa belum dalam taraf yang kritis, 4). Hasil belajar siswa yang kurang, dibuktikan dengan ketuntasan nilai siswa dalam tes terakhir yang masih rendah yaitu 11\%. Dampak dari permasalahan tersebut adalah kurangnya ketrampilan berpikir kritis siswa terhadap materi yang ada yang menjadikan hasil belajar PKn siswa rendah.

Berpikir kritis adalah pemikiran yang masuk akal dan flektif yang berfokus untuk memutuskan apa yang mesti dipercaya atau dilakukan (Norris \& Ennis,2009). Sedangkan menurut Fisher (2009) berpikir kritis adalah interpretasi dan evaluasi yang terampil dan aktif terhadap observasi dan komunikasi, informasi dan argumentasi.

Keterampilan berpikir kritis menurut Hernawan (2018) diidentifikasi menjadi lima kategori, yaitu: 1). Klarifikasi dasar, 2). Dukungan dasar, 3). Menyimpulkan, 4). Klarifikasi tingkat lanjut, 5). Strategi dan taktik. Dalam pengembangan kategori-kategori tersebut telah dijabarkan kedalam indikator-indikator. Berikut indikator-indikator ketrampilan berpikir kritis yang telah dijabarkan: 1). Melakukan klarifikasi dasar, 2). Menilai dukungan dasar, 3).membuat kesimpulan, 4).melakukan klarifikasi tingkat lanjut, 5).menerapkan strategi dan taktik dalam menyelesaikan masalah.

Tindakan yang dapat dilakukan untuk mengatasi masalah yang terjadi di kelas 2 SDN Bringin 3 adalah tindakan dengan metode yang tepat untuk mata pelajaran PKn yang akan mengajak siswa berpartisipasi secara aktif dalam kegiatan pembelajaran. Menurut Widodo (2012) metode khusus untuk PKn antara lain simulasi, role playing atau bermain peran, sosiodrama, dan partisipatorik. Kemudian menurut Tatiek (2006) salah satu tujuan dari bermain peran adalah melatih ketrampilan-ketrampilan tertentu melalui keterlibatan secara aktif dalam pembelajaran.

Metode bermain peran adalah suatu cara yang diterapkan dalam proses belajar mengajar dimana siswa diberikan kesempatan untuk melaksanakan kegiatan-kegiatan untuk menjelaskan sikap dan nilainilai serta memainkan tingkah laku atau peran tertentu sebagaimana terjadi dalam kehidupan masyarakat (Fathurrohman \& Wuryandani, 2012). Sedangkan menurut Tukiran(2012) bermain peran adalah metode mengajar yang mendramatisasikan sesuatu situasi sosial yang mengandung suatu problem, agar peserta didik dapat memecahkan suatu masalah yang muncul dari situasi sosial. 
Menurut Tatiek (2006) bermain peran dapat digunakan sebagai: 1). Alat untuk mendiagnosis dan mengerti seseorang dengan cara mengamati perilakunya waktu memerankan dengan spontan situasi dan kejadian yang terjadi dalam kehidupan sebenarnya, 2). Media pengajaran melalui proses modeling anggota dapat lebih efektif melalui keterampilan-keterampilan antar pribadi dengan mengamati berbagai cara dalam memecahkan masalah, 3). Metode latihan untuk melatih keterampilan-keterampilan tertentu melalui keterlibatan secara aktif dalam porses bermain peran.

Menurut Sanjaya (2006) dalam melaksanakan metode bermain peran terdapat 3 langkah yang harus diperhatikan agar mendapat hasil terbaik, yaitu: 1). Persiapan yang meliputi menentukan topik atau masalah serta tujuan yang akan dicapai, memberikan gambaran masalah dalam situasi yang akan diperankan, dan menetapkan pemain yang akan dilibatkan. 2). Pelaksanaan yang meliputi memulai kegiatan, membimbing siswa yang tidak terlibat, memberikan bantuan pada pemain yang kesulitan, dan menghentikan bermain peran ketika hendak mencapai puncak untuk merangsang siswa lain dalam menyelesaikan masalah yang diperankan. 3). Penutup yang meliputi melakukan diskusi dan mendorong siswa untuk memberikan kritik dan saran.

Melalui tindakan dengan penggunaan metode bermain peran diharapkan dapat meningkatkan ketrampilan berpikir kritis siwa dalam memecahkan masalah sehingga dapat meningkatkan hasil belajar siswa.

\section{Metode}

Penelitian ini berjenis Penelitian Tindakan Kelas (PTK). Menurut Tampubolon (2014) penelitian tindakan kelas adalah penelitian yang dilakukan oleh pendidik/calon pendidik dikelasnya sendiri secara kolaboratif/partisipasif untuk memperbaiki kinerja pendidik menyangkut kualitas proses pembelajaran, dan meningkatkan hasil belajar peserta didik, baik dari aspek akademik maupun non akademik, melalui tindakan reflektif berbentuk siklus (daur ulang). Penelitian ini menggunakan metode bermain peran untuk meningkatkan ketrampilan berpikir kritis dan hasil belajar siswa pada mata pelajaran PKn.

Subjek penelitian ini adalah siswa kelas 2 SDN Bringin 3 yang berjumlah 18 orang siswa dengan siswa laki-laki 12 orang siswa dan siswa perempuan 6 siswa. Penelitian ini dilakikan selama bulan Juli sampai Agustus tahun 2018 di SDN Bringin 3 Kecamatan Bringin Kabupaten Semarang.

Pada penelitian tindakan kelas ini, teknik pengumpulan data yang digunakann oleh peneliti adalah teknik tes dan non tes. Teknik pengumpulan data ini dilakukan dengan tujuan untuk mengetahui hasil belajar siswa setelah dilakukannya tindakan menggunakan metode bermain peran. Teknik tes digunakan $\backslash$ di setiap akhir siklus, baik siklus I maupun siklus II. Berdasarkan tes tersebut maka diperoleh data kuantitatif hasil belajar siswa yang akan disajikan dalam bentuk tabel dan grafik. Teknik non tes digunakan selama proses siklus I maupun siklus II berlangsung. Teknik non tes berupa lembar observasi guru dan siswa yang dilakukan oleh observer. Dari teknik non tes akan didapatkan hasil kualitatif.

Dalam penelitian ini, peneliti menggunakan teknik analisis data berupa deskripsi kuantitatif. Data diperoleh dari lembar observasi guru dan siswa yang berupa penjelasan atau keterangan berbentuk angka-angka selama dilangsungkannya siklus I dan siklus II. Kemudian data tersebut diolah dan dibandingkan untuk mengetahui perbedaan setelah dilakukan siklus I dan siklus II. Data yang akan diperoleh dalam penelitian ini berupa: 1). data hasil observasi kegiatan guru, 2). data hasil observasi ketrampilan berpikir kritis siswa, 3). data hasil tes evaluasi siswa dalam siklus I dan siklus II. Indikator keberhasilan penelitian ini adalah ketuntasan siswa yang mencapai 75\% dari jumlah seluruh siswa.

\section{Hasil dan Pembahasan}

Berdasarkan observasi dan wawancara di SDN Bringin 3, ditemukan data kondisi awal berupa: 1) pembelajaran yang terlihat satu arah dan berpusat pada guru, 2) dalam melaksanakan kegiatan pembelajaran, guru menggunakan satu metode yaitu metode ceramah dan belum mengembangkan metode lain yang lebih mengajak siswa untuk aktif berpartisipasi dalam pembelajaran, 3) dilihat dari cara siswa mengerjakan soal, siswa masih kesulitan dalam menganalisis dan memecahkan masalah yang ada dalam soal yang menjadikan ketrampilan berpikir kritis siswa belum dalam taraf yang cukup kritis atau kritis, 4) hasil belajar siswa yang kurang, dibuktikan dengan ketuntasan nilai siswa dalam tes terakhir yang masih rendah yaitu 11\%. Presentase tersebut masih jauh dari indikator keberhasilan yaitu sebesar 75\%. Untuk meningkatkan hasil belajar siswa, maka peneliti melakukan penelitian tindakan kelas. Penelitian yang menggunakan metode bermain peran ini diharapkan dapat meningkatkan ketrampilan berpikir kritis dan hasil belajar siswa dalam mata pelajaran PKn.

Kegiatan perencanaan dimulai dengan penyususnan Rencana Pelaksanaan Pembelajaran (RPP) selama dua siklus, dimana setiap siklus terdiri dari 3 pertemuan. Kompetensi dasar yang dipilih dalam 
penelitian ini adalah 1.1Mengenal pentingnya hidup rukun, saling berbagi, dan tolong menolong. 1.2Melaksanakan hidup rukun, saling berbagi, dan tolong menolong di rumah dan di sekolah. Kemudian kegiatan dalam tahap ini dilanjutkan dengan menyiapkan skrip bermain peran, membuat lembar observasi kegiatan guru dan lembar observasi ketrampilan berpikir krtitis siswa, serta membuat tes akhir untuk siklus I maupun siklus II.

Dalam pelaksanaan tindakan siklus I, baik pada pertemuan 1,2,maupun 3 guru memulai pembelajaran dengan memberi salam dan memimpin doa bersama serta mengecek absensi siswa. Dilanjutkan dengan kegiatan apresepsi tentang materi yang akan diajarkan, kemudian menjelaskan tentang KD dan tujuan yang akan dicapai pada setiap pertemuan. Guru juga menjelaskan tentang peraturan yang ada dikelas yaitu mengangkat tangan sebelum bertanya ataupun mengungkapkan pendapat.

Kemudian guru mulai menyampaikan materi dengan memberikan beberapa contoh gambar kepada siswa. Siswa diajak berdiskusi mengenai kegiatan yang ada digambar apakah sudah mencerminkan hidup rukun atau belum untuk selanjutnya siswa diajak menyimpulkan definisi dari hidup rukun dan menyebutkan contoh lain dari hidup rukun yang ada dilingkungan sekitar siswa. Selanjutnya guru mulai menjelaskan tentang kegiatan bermain peran, gambaran tentang peran yang akan dimainkan dan tujuan yang akan dicapai dalam bermain peran. Kemudian guru memilih dan metapkan siswa yang akan bermian peran dan membimbing siswa yang tidak bermain peran agar tetap memperhatikan. Guru juga berperan untuk membantu siswa yang mengalami kesulitan dalam menjalankan peran mereka. Saat bermain peran akan mencapai klimaks, guru menghentikan kegiatan bermain peran untuk kemudian meminta siswa untuk berdiskusi tentang jalnnya kegiatan bermain peran serta mengajak siswa untuk mengevaluasi materi yang diperankan apakah sudah sesuai dengan hidup rukun? Jika belum siswa diajak untuk memberikan saran bagaimana seharusnya yang dilakukan pemain agar dapat sesuai dengan hidup rukun. Kemudian diakhir pembelajaran, guru bersama dengan siswa melakukan refleksi tentang pembelajaran setiap harinya. Pada hari ketiga, kegiatan inti pembelajaran dijadikan evaluasi dengan mengerjakan tes tertulis.

Setelah dilaksanakannya siklus I, diadakan refleksi tentang kelebihan dan kekurangan yang terjadi selama siklus I melalui hasil observasi kegiatan guru yang dilakukan oleh observer. Kegiatan ini dilakukan untuk menemukan solusi dari kekurangan selama siklus I dan memperbaikinya di siklus II. Adapun kekurangan-kekurangan pada siklus I adalah sebagai berikut: 1). Kurangnya manajemen waktu guru, sehingga pada pertemuan ketiga, ada satu tahap yang harus terlewati yaitu membahas soal yang dirasa sulit untuk siswa, 2). Masih terdapat siswa yang tidak mematuhi aturan yang berlaku didalam kelas, seperti berjalan saat ada siswa lain yang sedang didepan kelas, 3). Ketuntasan belajar siswa pada siklus I yaitu 66,6\% siswa yang tuntas meningkat dibandingkan dengan ketuntasan belajar siswa sebelum diadakan tindakan yaitu $11 \%$. Hasil belajar siswa siklus I belum sesuai dengan indikator keberhasilan dalam penelitian yaitu $75 \%$ siswa tuntas.

Solusi yang digunakan untuk perbaikan pembelajaran pada siklus II adalah: 1). Memperbaiki manajemen waktu guru dengan menetapkan waktu dalam mengerjakan soal evaluasi dan tetap meminta lembar kerja siswa saat waktu sudah habis. 2). Memperbaiki aturan yang ada dengan mengajak siswa untuk berdiskusi aturan yang harus dilaksanakan selama pembelajaran berserta dengan hukuman jika melanggar. 3). Memperbaiki hasil belajar siswa dengan meneruskan ke siklus II guna mendapatkan hasil belajar yang memenuhi indikator keberhasilan.Berdasarkan solusi yang sudah ada, maka dilakukan perubahan dalam pelaksanaan siklus II tetapi masih dengan sintak pembelajaran yang sama dengan siklus I.

Data ketrampilan berpikir kritis siswa diperoleh dari hasil observasi yang dilakukan oleh observer dalam lembar kegiatan berpikir kritis siswa. Lembar observasi tersebut terdiri dari 5 indikator yang didapat dari beberapa ahli yaitu: 1) menganalisis definisi, 2) menilai perilaku yang sudah/belum tercermin dalam sikap seseorang, 3) menyimpulkan pentingnya sebuah sikap dalam kehidupan seharihari, 4) mengidentifikasi contoh perilaku seesorang dan membandingkan perilaku yang bertolak belakang, dan 5) mengevaluasi dengan memberikan saran. Data diperoleh dari jumlah skor indikator ketrampilan berpikir kritis dibagi dengan jumlah skor maksimal kemudian dikali 100. Berikut tabel ketrampilan berpikir kritis siswa. 
Tabel 1. Data Hasil Observasi Kemampuan Berpikir Kritis Siswa pada Siklus I dan Siklus II

\begin{tabular}{|c|c|c|c|c|c|}
\hline No & Indikator & Siklus I & Kategori & Siklus II & Ketegori \\
\hline 1 & Menganalisis definisi & 40 & Kurang kritis & 57 & Cukup kritis \\
\hline 2 & $\begin{array}{l}\text { Menilai perilaku yang } \\
\text { sudah/belum tercermin dalam } \\
\text { sikap seseorang. }\end{array}$ & 61 & Kritis & 75 & Kritis \\
\hline 3 & $\begin{array}{l}\text { Menyimpulkan pentingnya } \\
\text { sebuah sikap dalam kehidupan } \\
\text { sehari-hari. }\end{array}$ & 42 & Cukup kritis & 61 & Kritis \\
\hline 4 & $\begin{array}{l}\text { Mengidentifikasi contoh } \\
\text { perilaku seseorang dan } \\
\text { membandingkan perilaku yang } \\
\text { bertolak belakang. }\end{array}$ & 64 & Kritis & 72 & Kritis \\
\hline 5 & $\begin{array}{l}\text { Mengevaluasi dengan memberi } \\
\text { saran }\end{array}$ & 38 & Kurang kritis & 50 & Cukup kritis \\
\hline \multicolumn{2}{|c|}{ Rata-rata keseluruhan } & 49 & Cukup kritis & 63 & Kritis \\
\hline
\end{tabular}

Dari tabel diatas dapat dilihat bahwa terjadi peningkatan ketrampilan berpikir kritis siswa dari siklus I ke siklus II pada setiap indikatornya. Untuk lebih jelasnya, dapat dilihat dari diagram dibawah ini.

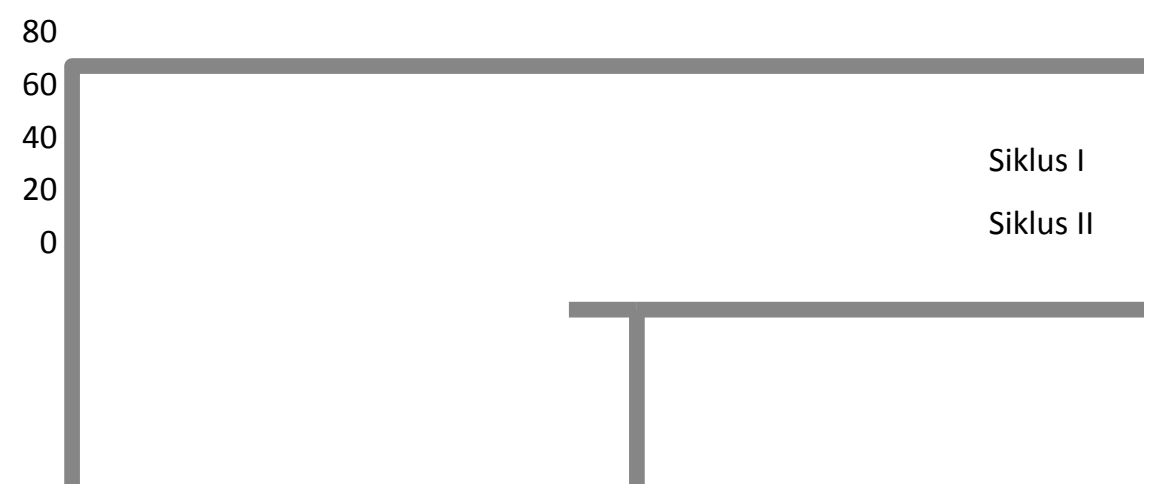

Diagram 1. Peningkatan Hasil Observasi Ketrampilan Berpikir Kritis Siswa

Berdasarkan gambar diatas, dapat dilihat bahwa terjadi peningkatan pada indikator menganalisis definisi yang semula pada siklus I sebesar 40 dengan kategori kurang kritis menjadi 57 dengan kategori cukup kritis pada siklus II. Pada indikator kedua yaitu menilai perilaku yang sudah/belum tercermin dalam sikap seseorang juga mengalami peningkatan dari skor 61 menjasi 75 dengan kategori kritis. Di indikator menyimpulkan pentingnya sebuah sikap dalam kehidupan sehari-hari terjadi peningkatan dari skor 42 dengan kategori cukup kritis pada siklus I menjadi 61 dengan kategori kritis pada siklus II. Dalam indikator selanjutnya yaitu mengidentifikasi contoh perilaku seseorang dan membandingkan perilaku yang bertolak belakang juga ada peningkatan dari skor 64 pada siklus I menjadi 72 pada siklus II dengan kategori tetap yaitu kritis. Dalam indikator terakhir mengevaluasi dengan memberi saran terdapat peningkatan dari skor 38 dengan kategori kurang kritis di siklus I menjadi 50 dengan kategori cukup kritis pada siklus II. Secara jumlah keseluruhan, rata-rata skor tiap indikator juga mengalami peningkatan dari skor 49 dengan kategori cukup kritis pada siklus I menjadi skor 63 dengan kategori kritis pada siklus II.

Data ketuntasan hasil belajar siswa diperoleh dari hasil nilai evaluasi siswa pada setiap akhir siklus dan data ketuntasan hasil belajar siswa pra siklus diperoleh dari nilai tes sebelum dilakukannya tindakan kelas. Berikut perbandingan ketuntasan siswa dalam pra siklus, siklus I dan siklus II. 
Tabel 2. Perbandingan Hasil Belajar PKn Pra Siklus, Siklus I dan Siklus II SD Negeri Bringin 3

\begin{tabular}{ccccccccc}
\hline No & Ketuntasan & \multirow{2}{*}{ KKM } & \multicolumn{2}{c}{ Pra Siklus } & \multicolumn{2}{c}{ Siklus I } & \multicolumn{2}{c}{ Siklus II } \\
& Belajar & & F & \% & F & $\%$ & F & $\%$ \\
\hline 1 & Tuntas & 275 & 2 & $11 \%$ & 12 & $66,7 \%$ & 15 & $83,3 \%$ \\
2 & Tidak Tuntas & $<75$ & 16 & $89 \%$ & 6 & $33,3 \%$ & 3 & $16,7 \%$ \\
& Total & & 18 & $100 \%$ & 18 & $100 \%$ & 18 & $100 \%$ \\
\hline
\end{tabular}

Dari tabel diatas dapat dilihat bahwa hasil belajar mata pelajaran PKn siswa kelas 2 sebelum dilakukannya tindakan terdapat 2 siswa atau $11 \%$ siswa yang dinyatakan tuntas dan terdapat 16 siswa atau $89 \%$ siswa yang dinyatakan belum tuntas. Kemudian setelah dilakukannya tindakan, hasil belajar siswa kelas 2 SDN Bringin 3 mengalami peningkatan dengan 12 siswa atau 66,7\% siswa tuntas dan 6 siswa atau 33,3\% siswa belum dinyatakan tuntas.Setelah dilakukannya siklus II, terdapat 15 orang siswa atau $83,3 \%$ siswa dinyatakan tuntas dan terdapat 3 orang siswa atau $16,7 \%$ siswa dinyatakan belum tuntas.

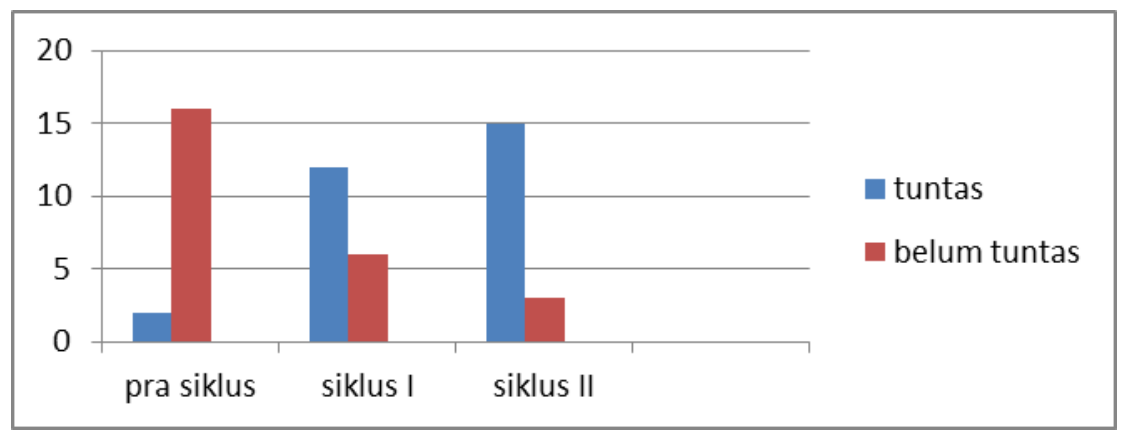

Diagram 2. Ketuntasan Hasil Belajar Siswa

Berdasarkan analisis data yang sudah tersaji pada data hasil penelitian diketahui bahwa metode bermain peran dapat meningkatkan ketrampilan berpikir kritis dan hasil belajar siswa kelas 2 SDN Bringin 3 pada mata pelajaran PKn. Keberhasilan tersebut dapat dilihat dari perbandingan nilai PKn pada pra siklus, siklus I dan siklus II.

Pada siklus Idata hasil observasi ketrampilan berpikir krtitis siswa yang diambil selama proses pembelajaran berlangsung menunjukkan bahwa dalam diskusi dan tanya jawab bersama guru siswa masih mengalami kesulitan dalam menganalisis definisi. Siswa terkesan mengulang-ulang kata kunci dengan tidak menjabarkannya ke dalam definisi yang lebih rinci. Seperti pengulangan kata rukun dalam menganalisis definisi hidup rukun. Siswa sudah mulai aktif mengungkapkan pendapat dalam menilai perilaku yang sudah atau belum mrencerminkan hidup rukun, mengidentifikasi contoh perilaku hidup rukun dan membandingkan perilaku yang bertolak belakang. Siswa juga terlihat antusias dalam menyebutkan contoh hidup rukun dikehidupan mereka tetapi hal ini justru menimbulkan keadaan kelas yang kurang kondusif. Sedangkan dalam mengevaluasi materi bermain peran maupun jalannya bermain peran banyak siswa yang masih diam dan takut mengungkapkan pendapat. Siswa jugamasih mengalami kesulitan dalam memberikan saran tentang materi dalam bermain peran ataupun jalannya bermain peran. Deskripsi tersebut tercermin dalam skor yang diperoleh siswa selama siklus I yaitu 49 dan masuk dalam kategori cukup kritis.

Setelah dilakukan refleksi terhadap kelebihan dan kekurangan selama siklus I maka ditemukan solusi untuk mengatasi kekurangan dalam siklus I. Kemudian peneliti membuat rencana perbaikan untuk siklus II. Terbukti dengan memberikan motivasi lebih kepada siswa, siswa lebih aktif menjawab selama diskusi berlangsung. Siswa juga lebih aktif dalam menganalisis definisi saling berbagi dan tolong menolong. Siswa dapat menjelaskan definisi tolong menolong dengan kata-kata mereka sendiri serta mampu menyimpulkan alasan mengapa saling berbagi dan tolong menolong penting bagi mereka dalam kehidupan sehari-hari. Dalam mengidentifikasi contoh perilaku saling berbagi dan tolong menolong serta membandingkan perilaku yang bertolak belakang untuk menilai perilaku yang sudah/belum sesuai dengan saling berbagi siswa terlihat lebih tertib dalam menyampaikan pendapatnya karena telah dilakukan perbaikan aturan kelas dalam siklus II. Siswa juga mulai berani melakukan evaluasi terhadap materi bermain peran maupun jalannya bermain peran seperti sikap apa yang seharusnya dilakukan pemeran agar sesuai dengan perilaku saling berbagi dan tolong menolong. Bahkan beberapa siswa mampu untuk memberikan saran kepada temannya yang melakukan kegiatan bermain peran. Deskripsi 
observasi peningkatan ketrampilan berpikir kritis siswa ini sesuai dengan skor yang juga mengalami peningkatan menjadi 63 dengan kategori kritis.

Ketuntasan hasil belajar siswa pada pra siklus adalah sebesar 11\% siswa tuntas dan $89 \%$ siswa tidak tuntas. Berdasarkan observasi yang telah dilakukan, hal ini dipengaruhi oleh kemampuan menganalisis soal untuk memecahkan masalah dan mencari solusi dari masalah siswa masih rendah. Terbukti dengan siswa yang masih bingung dalam mengerjkan soal dan jawaban siswa yang terkesan seadanya. Setelah dilakukannya tindakan pada siklus I, terjadi peningkatan ketuntasan hasil belajar siswa menjadi $66,7 \%$ siswa tuntas dan 33,3\% siswa belum tuntas. Dari hasil tes siklus I siswa terlihat sudah mulai memahami soal dan dapat mencari solusi dari masalah yang disajikan walaupun masih terdapat beberapa siswa yang belum sepenuhnya dapat memecahkan masalah yang disajikan. Siklus I dinyatakan belum berhasil karena indikator keberhasilan siswa tuntas $75 \%$ belum tercapai. Hal ini disebabkan siswa belum terbiasa dengan metode yang digunakan oleh peneliti. Oleh sebab itu penelitian dilanjutkan ke siklus II.

Sebelum melaksanakan siklus II, peneliti terlebih dahulu melakukan refleksi untuk mencari solusi dari kekurangan pada siklus I. Setelah dilakukan tindakan siklus II terjadi peningakatan ketuntasan hasil belajar siswa menjadi $83 \%$ siswaa tuntas dan $17 \%$ siswa tidak tuntas. Peningkatan ketrampilan berpikir kritis siswa juga terlihat meingkat dari kemampuan siswa dalam menganalisis definisi dan memecahkan masalah serta membuat kesimpulan dari soal yang disajikan.

Berdasarkan observasi dan refleksi tindakan yang telah dilakukan oleh guru, pelaksanaan tindakan pembelajaran pada pelajaran PKn dengan menggunakan metode bermain peran telah berjalan sesuai dengan yang diharapkan. Penggunaan metode bermain peran juga terbukti dapat meningkatkan ketrampilan berpikir kritis siswa sehingga dalam menjawab soal evaluasi siswa dapat lebih baik. Hal itu terbukti dengan meningkatntya ketuntasan hasil belajar siswa kelas 2 SDN Bringin 3 pada mata pelajaran PKn.

Hasil penelitian ini sejalan dengan penelitian yang dilakukan Ambang Aditya (2013) dengan judul "Peningkatan Hasil Belajar Siswa dalam Pembelajaran PKn melalui Metode Bermain Peran di Kelas 4 Semester 2 SDN Tirtomoyo Kecamatan Poncowerno Kebumen tahun 2012/2013". Penelitian ini menyatakan bahwa dengan menggunakan metode bermain peran dalam mata pelajaran PKn akan meningkatkan hasil belajar siswa.

Penelitian yang dilakukan oleh Musa Antiklas (2010) dengan judul "Upaya Peningkatan Keaktifan Siswa dalam Pembelajaran Pendidikan Kewarganegaraan melalui Model Bermain Peran di kelas IV semester 2 SDN 2 Kedawung Kec.Pejagongan Kabupaten Kebumen Tahun Pelajaran 2009/2010" menyimpulkan bahwa dengan penggunaan metode bermain peran dalam pembelajaran Pendidikan Kewarganegaraan akan meningkatkan keaktifan siswa.

\section{Simpulan dan Saran}

Berdasarkan hasil penelitian dan pembahasan dapat ditarik kesimpulan bahwa penggunaan metode bermain peran dalam mata pelajaran PKn dapat meningkatkan ketrampilan berpikir kritis dan hasil belajar siswa kelas 2 SDN Bringin 3. Peningkatan ketrampilan berpikir krtitis dapat dilihat dari terjadinya peningkatan pada indikator menganalisis definisi yang semula pada siklus I sebesar 40 dengan kategori kurang kritis menjadi 57 dengan kategori cukup kritis pada siklus II. Pada indikator kedua yaitu menilai perilaku yang sudah/belum tercermin dalam sikap seseorang juga mengalami peningkatan dari skor 61 menjasi 75 dengan kategori kritis. Di indikator menyimpulkan pentingnya sebuah sikap dalam kehidupan sehari-hari terjadi peningkatan dari skor 42 dengan kategori cukup kritis pada siklus I menjadi 61 dengan kategori kritis pada siklus II. Dalam indikator selanjutnya yaitu mengidentifikasi contoh perilaku seseorang dan membandingkan perilaku yang bertolak belakang juga ada peningkatan dari skor 64 pada siklus I menjadi 72 pada siklus II dengan kategori tetap yaitu kritis. Dalam indikator terakhir mengevaluasi dengan memberi saran terdapat peningkatan dari skor 38 dengan kategori kurang kritis di siklus I menjadi 50 dengan kategori cukup kritis pada siklus II. Secara jumlah keseluruhan, rata-rata skor tiap indikator juga mengalami peningkatan dari skor 49 dengan kategori cukup kritis pada siklus I menjadi skor 63 dengan kategori kritis pada siklus II. Peningkatan ketrampilan berpikir kritis siswa ini juga berpengaruh terhadap hasil belajar siswa. Dengan meningkatnya kemampuan siswa dalam menganalisis dan memecahkan soal yang diberikan, maka hasil belajar siswa juga meningkat. Terbukti dengan meningkatnya ketuntasan hasil belajar siswa dari pra siklus sebesar $11 \%$ siswa tuntas menjadi $66,7 \%$ siswa tuntas pada siklus I dan lebih meningkat menjadi $83 \%$ siswa tuntas pada siklus II.

Berdasarkan penelitian yang sudah dilakukan, peneliti menyampaikan saran sebagai berikut: 1) karena keterbatasan penelitian, untuk penelitian lanjut diharapkan adanya pengembangan materi dalam bermain peran, 2) saran untuk penerapan hasil penelitian, hasil penelitian dapat diterapkan untuk 
sekolah yang mempunyai karakteristik sama dengan sekolah yang diteliti untuk meningkatkan ketrampilan berpikir kritis dan hasil belajar PKn siswa.

\section{Daftar Rujukan}

Anam, K. Winarti dan Purwanto J. 2015. Evektivitas Pembelajaran Berbasis Metakognisis Untuk Meningkatkan Kemampuan Berpikir Kritis dan Minat Belajar Fisika Peserta Didik. Prosiding Seminar Nasional Sains dan Pendidikan Sains. Vol.5, No.1, 285- 294.

Bakry, N. (2011). pendidikan kewarganegaraan. Yogyakarta: Pustaka Pelajar Offset.

Daud F dan Hafsari, I. H. 2015. Sumbangan Keterampilan Berpikir Kritis dan Kesadaran Metakognitif pada Belajar Siswa Mengajar Biologi di SMA. Jurnal Modern Sains. Vol.9, No.12,143-153

Dedi, R. "Pengaruh Motivasi Belajar, Gaya Belajar dan Kemandirian Belajar terhadap Hasil Belajar Mahasiswa S1 PGSD Masukan Sarjana di UPBJJ UT Bandung". Jurnal Pendidikan Dasar. Volume 8, Nomor 2.

Dyner Rizki P, Lia Y, dan Sentot K. 2014. Keterkaitan Antara Pola Keterampilan Berpikir dengan bawah Penguasaan Konsep Siswa pada Pembelajaran Strategi Metakognisi Berbantuan Thinking Map. Indonesia journal of Applied Physics. Vol. 4, No. 2, Hal. 142-143.

Faturrohman, Wuryandani Wuri. (2011). Pembelajaran PKn di Sekolah Dasar. Yogyakarta: Nuha Litera.

Fatiah, A. 2014. Hubungan Pemahaman Konsep Dengan Keterampilan Berpikir kritis melalui Model pembelajaran Treffinger pada Mata Kuliah Fisika Dasar. Edusains, Vol. 6, No.1, Hal.88-89.

Fisher, A. (2009). Berpikir Kritis: Sebuah Pengantar. Erlangga.

Hernawan, a. (2018). Pengembangan Instrumen Asesmen. digilib unila .

Indriani, M. (2015). Upaya Meningkatkan Hasil Belajar Pkn Menggunakan Model Active Learning Tipe Role Reversal Question Pada Siswa Kelas V SD N Minomartani 6 Sleman Yogyakarta. Lumbung Pustaka $U N Y, 14$.

Nevy N. H, Wiyanto dan Achmad S. 2017. Analisis Kemampuan berpikir deduksi hipotesis terhadap pemahaman konsep rangkaian resistor pada listrik arus searah. Physics communication. Volume 1, Nomor 1, Halaman $35-42$.

Nurlaila, N., Suparmi, S., \& Sunarno, W. 2013. Pembelajaran Fisika Dengan PBL Menggunakan Problem Solving Dan Problem Posing Ditinjau Dari Kreativitas Dan Keterampilan Berpikir Kritis Siswa. INKUIRI: Jurnal Pendidikan IPA, Vol. 2 , No. 02.

Putra Gede A. 2014. Keterampilan Berpikir Kritis dan Pemahaman Konsep Siswa Pada Model Siklus Belajar Hipotetis Deduktif. Jurnal Pendidikan dan Pengajaran. Vol. 5, No.3, Hal. 201- 209.

Rahayuni Galuh. 2016. Hubungan Keterampilan Berpikir Kritis Dan Literasi Sains Pada Pembelajaran IPA Terpadu dengan Model PBM dan STM. Jurnal Penelitian dan Pembelajaran IPA. Vol. 2, No. 2, Hal.131-146.

Sanjaya, W. (2006). Strategi Pembelajaran Berorientasi Standar Proses Pendidikan. Bandung: Kencana.

Saepuzaman Duden dan Yustiadi. 2015. Profil Keterampilan Berpikir Kritis Siswa SMA Pada Materi Rangkaian Listrik Arus Searah. Prosiding Seminar Quantum (hlm. 56-58). Universitas Ahmad Dahlan.

Samsiyah, N., \& Rudyanto, H. E. (2015). Kemampuan Berpikir Kreatif Dalam Memecahkan Masalah Matetatika Open-Ended Ditinjau Dari Tingkat Kemampuan Matematika Siswa Sekolah Dasar. PEDAGOGIA: Jurnal Pendidikan, Volume 4, Nomor 1, 23-33. 
Slameto. (2010). Belajar dan Faktor-Faktor yang Mempengaruhinya. Rienka Cipta.

Sulasmono. (2010). pendidikan pancasila dan kewarganegaraan. salatiga: tisara grafika.

Tatiek. (2006). teori dan praktek bimbingan kelompok. malang: universitas negeri malang.

Tukiran. (2012). Metode Penelitian Survei. Jakarta: LP3ES.

Tampubolon, S. (2014). Penelitian Tindakan Kelas Sebagai Pengembangan Profesi Pendidik Dan Keilmuan. Jakarta: Penerbit Erlangga.

Widodo, t. (2012). Peningkatan Keaktifan Dan Hasil Belajar Siswa Dalam Pembelajaran PKN Melalui Metode Sosiodrama Di Kelas V. scholaria.

Wahdatun, Suyatno, Muslimin I. 2014. Imprementasi Model Siklus Belajar Hipotetikal Deduktif Untuk Meningkatkan Penguasaan konsep dan keterampilan Berpikir Kreatif Siswa SMA materi Pokok Larutan Penyangga. Jurnal Kimia FMIPA Universitas Negeri Surabaya .Vol. 3, No.2, 126-133. 